\title{
Epidemiological and Clinical Aspects of Neonatal Dermatoses at the National Teaching Hospital HKM of Cotonou Benin
}

\author{
Hugues Adegbidi 1* , Félix Atadokpede, Christiane Koudoukpo², Marcelline d'Almeida ${ }^{3}$, \\ Bérénice Dégboé ${ }^{1}$, Florence Alihonou ${ }^{3}$, Fabrice Akpadjan'1, Lydie Savoeda ${ }^{1}$, \\ Florencia do Ango-Padonou ${ }^{1}$
}

\begin{abstract}
${ }^{1}$ Department of Dermatology-Venereology, Faculty of Health Sciences of Cotonou, University of Abomey-Calavi, Abomey-Calavi, Benin

${ }^{2}$ Department of Dermatology-Venereology, Faculty of Medecine of Parakou, University of Parakou, Parakou, Benin ${ }^{3}$ Department of Pediatry, Faculty of Health Sciences of Cotonou, University of Abomey-Calavi, Abomey-Calavi, Benin Email: *adegbidih@yahoo.fr
\end{abstract}

How to cite this paper: Adegbidi, H., Atadokpede, F., Koudoukpo, C., d'Almeida, M., Dégboé, B., Alihonou, F., Akpadjan, F., Savoeda, L. and do Ango-Padonou, F. (2017) Epidemiological and Clinical Aspects of Neonatal Dermatoses at the $\mathrm{Na}$ tional Teaching Hospital HKM of Cotonou Benin. Journal of Cosmetics, Dermatological Sciences and Applications, 7, 204-210. https://doi.org/10.4236/jcdsa.2017.73019

Received: August 8, 2017

Accepted: September 8, 2017

Published: September 11, 2017

Copyright $\odot 2017$ by authors and Scientific Research Publishing Inc. This work is licensed under the Creative Commons Attribution International License (CC BY 4.0).

http://creativecommons.org/licenses/by/4.0/

(c) (i) Open Access

\begin{abstract}
Neonatal dermatoses (NND) are frequent, varied and of variable prognosis. The objective of this work was to study the epidemiological and clinical aspects of NND at the NTH-HKM. Methods: This was a cross-sectional descriptive and analytical study from December 1, 2014 to February 28, 2015. All newborns received in the Department of Pediatrics and Medical Genetics and with dermatosis were included. The diagnosis of dermatoses was clinical. Results: During the study period, 355 newborns had at least one NND on a total of 580 newborns received, a prevalence of $61.2 \%$. The sex ratio was 1.54 and the average age was 3.11 days. Transient dermatoses were more frequent $(80 \%)$, dominated by desquamation + xerosis $(33.75 \%)$. Congenital melanocytic nevi (40.74\%) and malformations and vascular tumors (18.52\%) were the most noted pathological neonatal dermatoses. Only age was statistically associated with NND. Conclusion: DNH is common in newborns at the NTH-HKM. They were mostly transitory. Pathological conditions should be treated where appropriate.
\end{abstract}

\section{Keywords}

Epidemiological and Clinical Aspects, Dermatoses, Newborns, Benin

\section{Introduction}

Neonatal dermatoses (NND) are mucocutaneous and/or phanerian disorders observed between the 1st and the 28th day of life. They are frequent, diverse and 
of variable prognosis [1]. They may be transient or constitute true pathologies requiring treatment. It is therefore important to recognize these dermatoses in order to carry out a good evaluation of each case in order to make an appropriate care. Few works have been done on the subject in Africa. The objective of this study is to study the epidemiological and clinical aspects of NND at the NTH-HKM in Cotonou.

\section{Methods}

This was a cross-sectional descriptive and analytical study that took place from December 1st, 2014 to February $28^{\text {th }}, 2015$. All newborns seen in consultation or hospitalized in the Department of Pediatrics and Medical Genetics dermatosis were included. The diagnosis of dermatoses was clinical. After the newborn was examined by a dermatologist, the parents were interviewed and the data supplemented using the newborn's medical record. Any child born before 37 weeks of amenorrhea was considered premature. It is post-term when gestational age was greater than 42 weeks of amenorrhea. Any birth weight greater than or equal to 2500 grams was normal. The data collected were recorded and processed with the EPI INFO software version 3.7. The $\mathrm{Chi}^{2}$ test was used to compare the proportions. The threshold of significance was $\mathrm{p}<0.05$.

Transient neonatal dermatoses: skin manifestations characterized mainly by their spontaneous reversibility, from a few minutes to a few days or weeks.

Pathologic neonatal dermatoses: cutaneous manifestations which do not heal spontaneously during the first month of life and which mostly require treatment.

\section{Results}

\subsection{General Characteristics of Newborns}

We examined 580 newborns, of whom 355 had at least one dermatosis. The prevalence of NND at the NTH-HKM was $61.2 \%$. Boys accounted for $60.56 \%$ and girls $39.44 \%$ of newborns included, with an average age of 3.11 days. Regarding gestational age, the term of pregnancy was imprecise for five (05) newborns. The general characteristics of newborns are summarized in Table 1.

\subsection{Clinical Features}

Transient dermatoses were found in 323 (80\%) newborns such as desquamation, xerosis, sudoral military, mongoloid spot, sebaceous hyperplasia toxic erythema ecchymosis and haematoma and melanic pustulosis. Pathological dermatoses were found in $81(20 \%)$ newborns such as congenital melanocytary nevus, vasculary lesions, infectious dermatosis, irrritative dermatosis, cutaneous malformations, ichtyosis and congenital non infectious bullous dermatosis.

Congenital melanocytic nevus was the most frequent pathological NND (40.74\%).

Table 2 and Table 3 respectively show the distribution of cases of transient NND and pathological NND. 
Table 1. General characteristics of newborns.

\begin{tabular}{ccc}
\hline Dernatoses & Transient & Pathological \\
\hline \multirow{2}{*}{ Sex } & $80 \%$ & $20 \%$ \\
& Male & Female \\
Age of newborns & $60.66 \%$ & $39.44 \%$ \\
& Less than 1 week & More than 1 week \\
Term & $90.98 \%$ & $9.02 \%$ \\
Newborn's weight & Prematurity & Post maturity \\
& $10 \%$ & $5.14 \%$ \\
Delivery's way & $\leq 2500$ gr & $>2500$ gr \\
& $84.79 \%$ & $15.21 \%$ \\
Gestity & Caesarean & Low \\
& $73.80 \%$ & $26.20 \%$ \\
Parity & Multigravida & Nulligeste \\
& $68.45 \%$ & $31.55 \%$ \\
& Multipare & Primipare \\
& $62.82 \%$ & $37.18 \%$ \\
\hline
\end{tabular}

Table 2. Sharing out of cases of transitional NND.

\begin{tabular}{ccc}
\hline Transitional dermatosis & Effectif & Percentage (\%) \\
\hline Desquamation + xerosis & 109 & 33.75 \\
Sudoral miliary & 72 & 22.29 \\
Mongoloïd spot & 69 & 21.36 \\
Sebaceous hyperplasia & 40 & 12.38 \\
Toxic erythema & 15 & 4.64 \\
Ecchymosis + Haematoma & 12 & 3.72 \\
Melanic pustulosis & 6 & 1.86 \\
TOTAL & 323 & 100
\end{tabular}

Table 3. Sharing out of cases of pathological NND.

\begin{tabular}{ccc}
\hline Pathological dermatosis & Effectif & Percentage (\%) \\
\hline Congenital melanocytary naevus & 33 & 40.74 \\
Vasculary lesions & 15 & 18.52 \\
Infectious dermatosis & 13 & 16.05 \\
Irritatives dermatosis & 10 & 12.35 \\
Cutaneous malformations & 5 & 6.17 \\
Ichtyosis & 3 & 3.70 \\
Congenital non infectious bullous dermatosis & 2 & 2.47 \\
TOTAL & 81 & 100
\end{tabular}

Figure 1 shows a case of congenital cystic lymphangioma vascular malformation.

The lesions were much more present in the glabrous skin (face, neck, trunk, limbs) with a predominance in the trunk (39.08\%) and then in the cephalic region $(34.45 \%)$. 


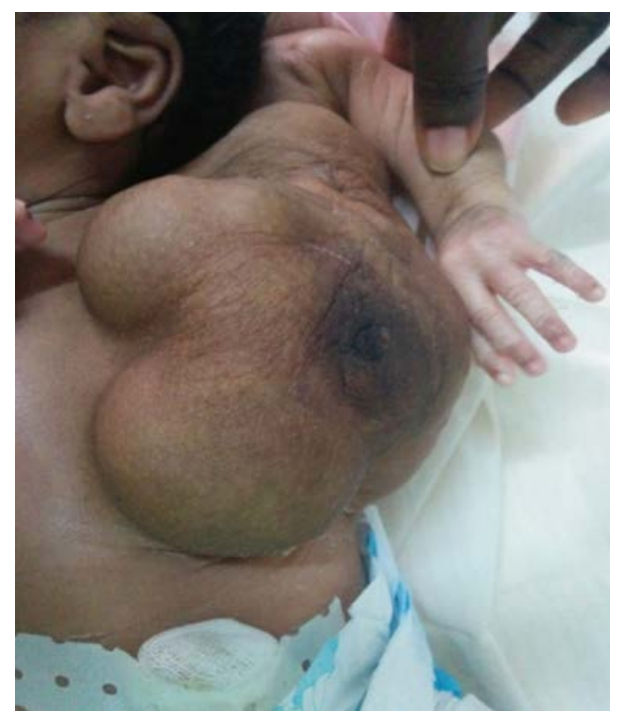

Figure 1. Congenital cystic lymphangioma of the left side of the thorax and shoulder.

\subsection{Correlation between NND and Neonatals Factors}

The correlation between NND and certain neonatal factors is given in Table 4 . It's appear that the age of the newborns have a correlation with the dermatosis witch are seen. We didn't find another significant correlation between neonatal factor and NND.

\section{Discussion}

Several studies have been carried out on the prevalence of NND in different countries and races. The literature reports a prevalence between $40 \%$ and $100 \%$ [2] [3]. The prevalence of $61.2 \%$ in our study is close to that reported by LORENZ S. (59.7\%) in Germany [4]. On the other hand, it is less than that obtained by EKIZ Ö. In Turkey (67.3\%), KANE A. in Senegal (94.2\%), TRAORE A. in Burkina Faso (95\%) and OYEDEJE OA in Nigeria 96\%) [8]. These different results can be related to study methods (multiplicity of study sites, longer study duration, age of newborns included) and racial characteristics.

The majority (80\%) of NNDs were transient as reported by many other authors [5] [6] [8] [9]. This is due to the fact that these dermatoses are phenomena of physiological adaptation to the air environment and linked to intrauterine life. Of these, the most frequent were desquamation + xerosis (33.75\%), sweating miliary (22.29\%), mongoloid spots (21.36\%) and sebaceous hyperplasia (12.38\%). These neonatal dermatoses were also the most noted in Senegalese newborns except for the sudoral miliary [6]. The Sahelian-Senegalese climate of Senegal could explain this low rate of sweat miliary observed. KANE A. and FERHABAS A. noted in Senegal and Turkey that desquamation + xerosis was the most frequent dermatosis [6] [10] as we observed (33.75\%) at rates of $41 \%, 43 \%$ and $39.5 \%$ respectively. These results are in the range of $72 \%$ to $83 \%$ reported in the literature [11] [12]. In our study, miliary sweat was the second (22.29\%) NND 
Table 4. Correlation between NND and neonatals factors.

\begin{tabular}{|c|c|c|}
\hline Maternals and neonatals factors & Effectif & $\mathrm{p}$ \\
\hline \multicolumn{3}{|c|}{ Newborns' age } \\
\hline$<7$ days & 323 & 0.000 \\
\hline$>7$ days & 32 & \\
\hline \multicolumn{3}{|c|}{ Sex } \\
\hline Male & 215 & 0.635 \\
\hline Femal & 140 & \\
\hline \multicolumn{3}{|c|}{ Pathway of delivery } \\
\hline Cesarean section & 262 & 0.711 \\
\hline Lower way & 93 & \\
\hline \multicolumn{3}{|c|}{ Gestationnal age } \\
\hline Premature & 35 & 0.157 \\
\hline Term & 297 & \\
\hline Post-term & 18 & \\
\hline \multicolumn{3}{|l|}{ Born weight } \\
\hline$<2500 \mathrm{~g}$ & 54 & 0.652 \\
\hline$>2500 \mathrm{~g}$ & 301 & \\
\hline \multicolumn{3}{|l|}{ Mother's parity } \\
\hline Primipara & 132 & 0.157 \\
\hline Multipare & 223 & \\
\hline
\end{tabular}

most encountered as in Nigerian newborns (24.6\%) [8]. SACHDEVA M. had a rate of $23.8 \%$ of sweat miliary in Indian infants [12], similar to that of our study. On the other hand, TRAORE A. in Burkina Faso had as first neonatal dermatosis the sweat miliary with a rate of $31.1 \%$ [7]. This higher rate may be related to climatic conditions and the study period. The rates of mongoloid spot (21.36\%) and sebaceous hyperplasia (12.38\%) noted in our study are close to those obtained by KANE A. in Senegalese newborns (23.72\% for Mongoloid spots and $16.51 \%$ for sebaceous hyperplasia) [6]. As for the pathological DNN, the congenital melanocytic nevus came first (40.74\%) as in the KANE A. study (39.6\%) [6]. The second pathological DNN we noted was the malformations and vascular tumors with a proportion of $18.52 \%$. This rate is close to those of CHAITHIRAYANON S. (16.9\%) [13] and FERAHBAS A. (19.2\%) [10].

The majority of the NNDs concerned the glabrous skin in our study as also noted KANE A. [6]. The trunk was the most affected anatomical zone followed by the cephalic part (scalp + face + neck). This is consistent with the results of TRAORE A. in Burkina Faso [7].

Different studies have been conducted on the correlation between NNDs and some maternal and neonatal factors. In our series, out of the age of newborn babies, no statistically significant relationship could be established with the other factors studied (sex, gestational age, childbirth, birth weight, parity of mothers). TRAORE A, SACHDEVA M and JAIN N [7] [12] [14] also did not find a corre- 
lation between the NND factors mentioned above. However, HAVERI FTTS. [15] as well as SHEHAB M. [16] noted that birth weight was statistically associated with NND. This may be due to the difference in the method of study (inclusion and exclusion criteria).

\section{Conclusion}

This study allowed us to take stock of the NND at the NTH-HKM given that no data existed on the subject in Benin. It shows us that NNDs are common among newborns at the NTH-HKM. Transient dermatoses were predominant and should be distinguished from pathological dermatoses for possible treatment. Further in-depth investigations, whether or not to specifically link each DNN to particular factors, should be conducted.

\section{Conflicts of Interest}

No conflicts of interest to declare.

\section{References}

[1] Barbarot, S. and Stalder, J.F. (2003) Dermatologie néonatale. Encycl Méd Chir (Elsevier, Paris), Dermatologie, 98-860-A-10, 18 p.

[2] El-Moneim, A.A. and El-Dawela, R.E. (2012) Survey of Skin Disorders in Newborns: Clinical Observation in an Egyptian Medical Centre Nursery. Eastern Mediterranean Health Journal, 18, 49-55.

[3] Baruah, C.M., Bhat, V., Bhargava, R., Garg, R.B. and Ku (1991) Prevalence of Dermatoses in the Neonates in Pondichery. Indian Journal of Dermatology, Venereology and Leprology, 57, 25-28.

[4] Lorenz, S., Maier, C., Segerer, H., Landthaler, M. and Hohenleutner, U. (2000) Skin Changes in Newborn Infants in the First 5 Days of Life. Hautarzt, 51, 396-400. https://doi.org/10.1007/s001050051140

[5] Ekiz, Ö., Gül, Ü., Mollamahmutoglu, L. and Gönül, M. (2013) Skin Findings in Newborns and Their Relationship with Maternal Factors: Observational Research. Annals of Dermatology, 25, 1-4. https://doi.org/10.5021/ad.2013.25.1.1

[6] Kane, A., Anjembe, E.C., Diallo, M., Sy, T.N.D. and Ndiaye, B. (2003) Dermatoses néonatales à Dakar. Etude prospective portant sur 3355 enfants. Annales De Dermatologie Et De Venereologie, 130, 53.

[7] Traore, A., Barro-Traore, F., Guiguemde, A., Niamba, P., Diatto, N.G., Andonaba, J.B., et al. (2007) Aspects épidémiologiques et cliniques des dermatoses néonatales en milieu noir africain. Annales De Dermatologie Et De Venereologie, 134, 67. https://doi.org/10.1016/S0151-9638(07)89107-1

[8] Oyedeji, O.A., Joel-Medewase, V.I., Ogunlesi, T.A. and Oyedeji, G.A. (2008) Dermatoses in the Nigerian Newborn. Research Journal of Medical Sciences, 2, 19-22.

[9] Agarwal, G., Kumar, V., Ahmad, S., Goel, K., Goel, P., Prakash, A., et al. (2012) A Study on Neonatal Dermatosis in a Tertiary Hospital of Western Uttar Pradesh India. Journal of Community Medicine \& Health Education, 2, 169.

[10] Ferahbas, A., Utas, S., Akcakus, M., Gunes, T. and Mistik, S. (2009) Prevalence of Cutaneous Findings in Hospitalized Neonates: A Prospective Observational Study. Pediatric Dermatology, 26, 139-142. 
https://doi.org/10.1111/j.1525-1470.2009.00903.x

[11] Gokdemir, G., Erdogan, H.K., Koslu, A. and Baksu, B. (2009) Cutaneous Lesions in Turkish Neonates Born in a Teaching Hospital. Indian Journal of Dermatology, Venereology and Leprology, 75, 638. https://doi.org/10.4103/0378-6323.57742

[12] Sachdeva, M., Kaur, S., Nagpal, M. and Dewan, S.P. (2002) Cutaneous Lesions in Newborn. Indian Journal of Dermatology, Venereology and Leprology, 68, 334-337.

[13] Chaithirayanon, S. and Chunharas, A. (2013) A Survey of Birthmarks and Cutaneous Lesions in Newborns. Journal of the Medical Association of Thailand, 96, 49-53.

[14] Jain, N., Rathore, B.S. and Krishna, A. (2014) Dermatoses in Indian Neonates: A Clinical Study. Egyptian Journal of Dermatology and Venereology, 34, 86-92. https://doi.org/10.4103/1110-6530.150255

[15] Haveri, F.T.T.S. and Inamadar, A.C. (2014) A Cross Sectional Prospective Study of Cutaneous Lesions in Newborn. ISRN Dermatology, 2014, Article ID: 360590.

[16] Shehab, M.M., Youssef, D.M. and Khalil, M.M. (2015) Prevalence of Cutaneous Skin Lesions in Neonatal Intensive Care Unit: A Single Center Study. Journal of Clinical Neonatology, 4, 169-172. https://doi.org/10.4103/2249-4847.159872

Submit or recommend next manuscript to SCIRP and we will provide best service for you:

Accepting pre-submission inquiries through Email, Facebook, LinkedIn, Twitter, etc. A wide selection of journals (inclusive of 9 subjects, more than 200 journals)

Providing 24-hour high-quality service

User-friendly online submission system

Fair and swift peer-review system

Efficient typesetting and proofreading procedure

Display of the result of downloads and visits, as well as the number of cited articles

Maximum dissemination of your research work

Submit your manuscript at: http://papersubmission.scirp.org/

Or contact jcdsa@scirp.org 